\title{
RUMAH SEHAT DENGAN KEKAMBUHAN PADA PENDERITA ASMA
}

\section{HEALTHY HOUSEHOLD WITH HEALTH IN ASMA PATIENTS}

\author{
Andri Yulianto \\ Dosen STIKes Muhammadiyah Pringsewu Lampung
}

\begin{abstract}
ABSTRAK
Salah satu penyakit yang menjadi masalah kesehatan secara global didunia adalah asma. Di Provinsi Lampung tahun 2011 angka prevalensi penyakit asma 85\% dengan kesembuhan/Cure Rate 59,64\%. Kabupaten Lampung Utara merupakan salah satu kabupaten yang ada di Provinsi Lampung dengan jumlah penduduk 616.194 jiwa. Salah satu faktor yang dapat mempengaruhi terjadinya kekambuhan asma adalah kondisi rumah yang tidak sehat. Tujuan penelitian ini untuk mengetahui hubungan rumah sehat dengan kekambuhan pada penderita Asma di Wilayah Kerja Puskesmas Cempaka Kecamatan Sungkai Jaya Kabupaten Lampung Utara Tahun 2012. Jenis penelitian yang digunakan analitik dengan pendekatan cross sectional. Populasi dalam penelitian ini penderita asma sebesar 110 orang, sampel didapat 53 orang, pengambilan sampel menggunakan random sampling metode lottre. Analisis penelitian menggunakan chi square. Hasil uji statistik univariat didapat responden dengan kategori rumah sehat tidak memenuhi syarat sebesar 32 orang $(60,4 \%)$, responden dengan kategori mengalami kekambuhan asma sebanyak 35 orang $(66,0 \%)$. Hasil uji statistik chi square diperoleh ada hubungan yang bermakna antara rumah sehat dengan kekambuhan pada penderita Asma ( $\mathrm{p}$ value $<$ dari $\alpha, 0,046<0,05$ ). Diharapkan bagi petugas kesehatan di Puskesmas Cempaka untuk trus mensosialisasikan kriteria rumah sehat yang memenuhi syarat dan memodifikasi rumah yang telah ada secara terperinci dan jelas untuk menghindari terjadinya kekambuhan pada penderita asma.
\end{abstract}

Kata kunci: Rumah sehat, Kekambuhan Asma.

\begin{abstract}
One of the diseases that become a global health problem in the world is asthma. In Lampung Province in 2011 the prevalence rate of asthma 85\% with healing / Cure Rate 59.64\%. North Lampung Regency is one of the regencies in Lampung Province with a population of 616,194 people. One of the factors that can affect the occurrence of asthma relapse is an unhealthy home condition. The purpose of this study to determine the relationship of healthy homes with recurrence in people with asthma in the Work Area Puskesmas Cempaka Sungkai Jaya District North Lampung Year 2012. The type of research used analytical with cross sectional approach. The population in this study people with asthma of 110 people, samples obtained 53 people, sampling using random sampling method lottre. Analysis of the study using chi square. Univariate statistic test results obtained respondents with the category of healthy house does not meet the requirements of 32 people $(60.4 \%)$, respondents with the category of asthma relapse of 35 people $(66.0 \%)$. The result of chi square statistic test showed that there was a significant correlation between healthy house with relapse in Asthma sufferer ( $p$ value $<_{\text {of }} \dot{\alpha}, 0,046<0,05$ ). It is hoped for health workers at Puskesmas Cempaka to trus socialize criteria of eligible healthy homes and modify existing homes in detail and clear to avoid recurrence in asthma sufferers.
\end{abstract}

Keywords: Healthy Home, Asthma Relapse. 


\section{PENDAHULUAN}

Salah satu penyakit yang menjadi masalah kesehatan secara global didunia adalah asma. Berdasarkan data WHO (World Health Organization) tahun 2006, sebanyak 300 juta orang menderita asma dan 225 ribu penderita meninggal karena asma di seluruh dunia. Angka kejadian asma 80\% terjadi di negara berkembang akibat kemiskinan, kurangnya tingkat pendidikan, pengetahuan dan fasilitas pengobatan. Angka kematian yang disebabkan oleh penyakit asma di seluruh dunia diperkirakan akan meningkat $20 \%$ untuk sepuluh tahun mendatang, jika tidak terkontrol dengan baik. ${ }^{1}$

Hasil penelitian International study on asthma and alergies in childhood pada tahun 2006, menunjukkan bahwa di Indonesia prevalensi gejala penyakit asma meningkat dari $4,2 \%$ menjadi $5,4 \%$ ditahun 2007. ${ }^{9}$ Di Indonesia setiap tahunnya terjadi 175.000 kematian akibat asma dan terdapat 450.000 kasus asma. Tiga perempat dari kasus asma ini terdiri dari usia produktif (15 - 50 tahun). Pada tahun 2008 terdapat peningkatan kasus asma menjadi 478.000 kasus dengan tingkat kematian sebesar 201.000. ${ }^{1}$

Di Provinsi Lampung tahun 2011 angka prevalensi penyakit asma $85 \%$ dengan
kesembuhan/Cure Rate 59,64\%. Untuk itu masih banyak yang harus diperbaiki dan ditingkatkan karena angka kesembuhan asma ini belum mencapai target $\geq 85 \%$. Data terakhir yang diperoleh Dinas Kesehatan pada tahun 2011 kejadian asma mencapai 12.451 dengan kesembuhan/Cure Rate $68,12 \%$ lebih kecil dari target pada Standar Pelayanan Minimal yaitu $84 \%{ }^{4}$

Kabupaten Lampung Utara merupakan salah satu kabupaten yang ada di Provinsi Lampung dengan jumlah penduduk 616.194 jiwa. Pada tahun 2011 penderita asma berjumlah 1.507 penderita $(0,24 \%)$ dengan angka kekambuhan sebanyak 3 orang per 100 penderita asma. Wilayah kerja Puskesmas Cempaka Kecamatan Sungkai Jaya merupakan daerah penyumbang penderita Asma terbesar dengan angka kesakitan pada periode Januari-Desember 2011 sebanyak 110 orang $(20,37 \%)$ dan merupakan penyakit urutan 6 terbesar. ${ }^{3}$

Penyakit asma tidak dapat disembuhkan, namun dalam penggunaan obat-obat yang ada saat ini hanya berfungsi untuk menghilangkan gejala saja. Untuk mengontrol gejala asma secara baik, maka penderita harus bisa merawat penyakitnya, dengan cara mengenali lebih jauh tentang penyakit tersebut termasuk faktor pencetus kekambuhan asma. Mengingat hal tersebut 
pengelolaan asma yang terbaik haruslah dilakukan pada saat dini dengan berbagai tindakan pencegahan agar penderita tidak mengalami serangan ulang atau kekambuhan. ${ }^{9}$

Salah satu faktor yang dapat mempengaruhi terjadinya kekambuhan asma adalah kondisi rumah yang tidak sehat. Konsep tatanan rumah tangga sehat adalah pengaturan rumah sehat yaitu keadaan rumah sebaiknya tidak lembab, cukup ventilasi dan cahaya matahari, kebersihan lantai, kamar tidur sebaiknya sesedikit mungkin berisi barang-barang untuk menghindari debu rumah. Rumah sehat merupakan salah satu faktor pendukung kesehatan bagi penghuninya, kondisi yang tidak memenuhi syarat kesehatan dapat menjadi faktor predisposisi kambuhnya suatu penyakit salah satunya asma. ${ }^{9}$

Hasil pra survei yang dilakukan peneliti pada tanggal 11 Januari 2012 di Wilayah kerja Puskesmas Cempaka Kecamatan Sungkai Jaya Kabupaten Lampung Utara melalui wawancara bebas terhadap 10 orang penderita asma didapatkan $7 \quad(70 \%)$ mengatakan sering mengalami kekambuhan asma. Dari hasil observasi kondisi rumah terhadap 7 orang yang sering mengalami kekambuhan asma tersebut didapatkan 7 (100\%) kondisi rumah tidak sehat hal ini dapat dirasakan dari sirkulasi udara melalui ventilasi udara tidak lancar, sinar matahari tidak masuk kedalam rumah secara maksimal ditandai suasana pencahayaan dalam rumah yang remangremang, tempat masak pun tidak ada tempat pembuangan asap melalui genting, selain itu kondisi lantai rumah adalah tanah yang berdebu.

\section{METODE}

Penelitian ini adalah analitik dengan pendekatan crossectional yaitu desain penelitian yang bertujuan untuk mencari hubungan antara faktor resiko dengan efek pengamatan atau observasi antar variabel dilakukan secara bersamaan. ${ }^{8}$ Dan dilakukan pada bulan April - Mei 2012 di Puskesmas Cempaka Kecamatan Sungkai Jaya. Populasi dalam penelitian ini adalah penderita asma di wilayah kerja Puskesmas Cempaka Kecamatan Sungkai Jaya Kabupaten Lampung Utara yang berjumlah 53 dengan Teknik pengambilan sampel menggunakan simple random sampling metode lottre. ${ }^{6}$. Alat pengumpul data pada penelitian ini adalah lembar observasi yang berisi 13 pertanyaan tentang rumah sehat Sedangkan untuk variabel kekambuhan pada penderita asma menggunakan lembar kuesioner yang berisi 1 pertanyaan dengan 2 
alternatif jawaban Ya dan Tidak. Uji statistik Chi square, Taraf kesalahan yang digunakan adalah $5 \%{ }^{5}$

\section{HASIL}

\section{Analisa Univariat}

\section{Distribusi frekuensi rumah sehat}

Berdasarkan hasil pengumpulan data mengenai rumah sehat diperoleh hasil sebagai berikut:

\section{Tabel 1}

Distribusi frekuensi responden berdasarkan rumah sehat di Wilayah Kerja Puskesmas

Cempaka Kecamatan Sungkai Jaya Kabupaten Lampung Utara

\begin{tabular}{ccc}
\hline Rumah sehat & Jumlah & $\begin{array}{c}\text { Prosentase } \\
(\%)\end{array}$ \\
\hline $\begin{array}{c}\text { Memenuhi } \\
\text { syarat }\end{array}$ & 21 & $\mathbf{3 9 , 6}$ \\
\hline $\begin{array}{c}\text { Tidak } \\
\text { memenuhi } \\
\text { syarat }\end{array}$ & $\mathbf{3 2}$ & $\mathbf{6 0 , 4}$ \\
\hline Total & $\mathbf{5 3}$ & $\mathbf{1 0 0 , 0}$ \\
\hline
\end{tabular}

Berdasarkan tabel diatas distribusi frekuensi responden berdasarkan rumah sehat di Wilayah Kerja Puskesmas Cempaka dapat diketahui responden dengan kategori rumah sehat memenuhi syarat sebesar 21 orang $(39,6 \%)$ dan kategori rumah sehat tidak memenuhi syarat sebesar 32 orang $(60,4 \%)$.

\section{Distribusi frekuensi kekambuhan pada} penderita Asma

Berdasarkan hasil pengumpulan data mengenai kekambuhan pada penderita Asma diperoleh hasil sebagai berikut:

Tabel 2

Distribusi frekuensi responden berdasarkan kekambuhan pada penderita Asma di Wilayah Kerja Puskesmas Cempaka Kecamatan Sungkai Jaya Kabupaten Lampung Utara

\begin{tabular}{c|c|c}
\hline $\begin{array}{c}\text { Kekambuhan } \\
\text { pada penderita } \\
\text { Asma }\end{array}$ & Jumlah & $\begin{array}{c}\text { Prosentase } \\
(\%)\end{array}$ \\
\hline Tidak kambuh & $\mathbf{1 8}$ & $\mathbf{3 4 , 0}$ \\
\hline Kambuh & $\mathbf{3 5}$ & $\mathbf{6 6 , 0}$ \\
\hline Total & $\mathbf{5 3}$ & $\mathbf{1 0 0}$ \\
\hline
\end{tabular}

Berdasarkan tabel diatas distribusi frekuensi berdasarkan kekambuhan pada penderita Asma di Wilayah Kerja Puskesmas Cempaka dapat diketahui responden dengan kategori tidak mengalami kekambuhan asma sebesar 18 orang $(34,0 \%)$ dan responden dengan kategori mengalami kekambuhan asma sebanyak 35 orang $(66,0 \%)$.

\section{Analisa Bivariat}

Hubungan rumah sehat dengan kekambuhan pada penderita Asma

Hasil uji chi square antara variabel hubungan rumah sehat dengan kekambuhan pada penderita Asma didapat hasil sebagai berikut: 
Tabel 3

Hubungan rumah sehat dengan kekambuhan pada penderita Asma di Wilayah Kerja Puskesmas Cempaka Kecamatan Sungkai Jaya Kabupaten Lampung Utara

\begin{tabular}{|c|c|c|c|c|c|c|c|c|}
\hline \multirow{3}{*}{$\begin{array}{c}\text { Rumah } \\
\text { sehat }\end{array}$} & \multicolumn{4}{|c|}{\begin{tabular}{|c|} 
Kekambuhan pada \\
penderita Asma
\end{tabular}} & \multirow{3}{*}{$\mathrm{N}$} & \multirow{3}{*}{$\%$} & \multirow{3}{*}{$\begin{array}{c}\mathrm{P} \\
\text { valu } \\
\mathrm{e}\end{array}$} & \multirow{3}{*}{ OR } \\
\hline & \multicolumn{2}{|c|}{$\begin{array}{c}\text { Tidak } \\
\text { Kambuh } \\
\end{array}$} & \multicolumn{2}{|c|}{ Kambuh } & & & & \\
\hline & $\mathrm{n}$ & $\%$ & $\mathrm{n}$ & $\%$ & & & & \\
\hline $\begin{array}{l}\text { Memen } \\
\text { uhi } \\
\text { syarat }\end{array}$ & 11 & $\begin{array}{l}52 \\
, 4\end{array}$ & 10 & $\begin{array}{l}47 \\
, 6\end{array}$ & 21 & $\begin{array}{l}10 \\
0\end{array}$ & $\begin{array}{c}0,04 \\
6\end{array}$ & $\begin{array}{c}3,92 \\
9\end{array}$ \\
\hline $\begin{array}{l}\text { Tidak } \\
\text { memenu } \\
\text { hi syarat }\end{array}$ & 7 & $\begin{array}{l}21 \\
, 9\end{array}$ & 25 & $\begin{array}{l}78 \\
, 1\end{array}$ & 32 & $\begin{array}{l}10 \\
0\end{array}$ & & \\
\hline $\mathrm{N}$ & 18 & $\begin{array}{l}34 \\
, 0\end{array}$ & 35 & $\begin{array}{l}66 \\
, 0\end{array}$ & 53 & $\begin{array}{l}10 \\
0\end{array}$ & & \\
\hline
\end{tabular}

Berdasarkan tabel diatas dapat diketahui bahwa $52,4 \%$ atau 11 dari 21 responden dengan kategori rumah sehat memenuhi syarat tidak mengalami kekambuhan asma, Sedangkan $78,1 \%$ atau 25 dari 32 responden dengan kategori rumah sehat tidak memenuhi syarat mengalami kekambuhan asma. Hasil uji statistik chi square didapat nilai $\mathrm{p}$ value $<$ dari $\alpha \quad(0,046$ $<0,05)$ yang artinya Ho ditolak, ada hubungan yang bermakna antara rumah sehat dengan kekambuhan pada penderita Asma. OR didapat 3,929 yang berarti responden dengan rumah sehat tidak memenuhi syarat berpeluang mengalami kekambuhan asma sebesar 3,929 dibandingkan responden dengan rumah sehat memenuhi syarat.

\section{PEMBAHASAN}

\section{Rumah Sehat}

Berdasarkan hasil penelitian rumah sehat dapat diketahui responden dengan kategori rumah sehat memenuhi syarat sebesar 21 orang $(39,6 \%)$ dan kategori rumah sehat tidak memenuhi syarat sebesar 32 orang $(60,4 \%)$. Artinya lebih banyak responden yang tidak memiliki rumah dengan kriteria kondisi sirkulasi udara dan pencahayaan dari ventilasi yang tidak baik, kondisi lantai yang tidak bersih dan barangbarang dikamar kotor dan berdebu.

Hasil ini sejalan dengan penelitian Diana di Posyandu Gendingan Kecamatan Ngampilan Yogyakarta tahun 2005 yang menyatakan sebagian besar sanitasi rumah pada masyarakat tidak memenuhi syarat dengan prosentase $(76 \%)^{2}$

Menurut peneliti tingginya proporsi rumah sehat dalam kategori tidak memenuhi syarat karena disebabkan adanya kaitan dengan rendahnya pengetahuan masyarakat tentang kriteria rumah sehat yang memenuhi syarat dirumah tangga. Menurut beberapa responden selama ini petugas kesehatan tidak pernah mensosialisasikan kriteria rumah sehat yang memenuhi syarat. Rendahnya pengetahuan masyarakat dapat menjadi faktor predisposisi yang diwujudkan kedalam tindakan masyarakat 
untuk tidak memperhatikan dan menerapkan pengetahuan tersebut kriteria rumah sehat yang memenuhi syarat. Hal ini sesuai dengan teori ${ }^{8}$ yang mengatakan "pengetahuan merupakan domain terpenting terbentuknya perilaku seseorang". Kemungkinan kedua menurut peneliti adalah kondisi sosial ekonomi masyarakat yang rendah, menurut responden pendapatan keluarga perbulan rata-rata kurang dari $\mathrm{Rp}$ 700.000. Rendahnya status sosial ekonomi dapat menjadi faktor predisposisi responden lebih mementingkan pemenuhan kebutuhan keluarga sehari-hari dan tidak dapat mengalokasikan pendapatan untuk tersebut untuk memenuhi kriteria rumah sehat yang memenuhi syarat dalam bentuk membuat lantai dari semen, membuat ventilasi yang baik sehingga sirkulasi udara dan pencahayaan dapat masuk, dan membuat kamar baru untuk menempatkan barangbarang bekas dan kotor sehingga tidak menumpuk dikamar tidur. Hal ini sesuai dengan pendapat azrul azwar karakteristik manusia meliputi sosial ekonomi merupakan faktor yang dapat membentuk perilaku seseorang.

Begitupun sebaliknya responden dengan kategori rumah sehat yang memenuhi syarat, kemungkinan pertama responden telah mengetahui informasi mengenai syarat rumah sehat baik kriteria maupun dampak negatif jika rumah tidak sehat yang bisa didapat dari akses informasi media cetak maupun elektonik serta aktif bertanya kepetugas kesehatan. Informasi yang didapat tersebut membentuk suatu pengetahuan yang diwujudkan kedalam tindakan untuk berperilaku memenuhi rumah sehat yang memenuhi syarat. Kemungkinan kedua adalah tingginya status ekonomi responden berdasarkan pendapatan juga dapat menjadi faktor predisposisi responden mampu mengalokasikan pendapatan untuk memenuhi kriteria rumah sehat.

\section{Kekambuhan asma}

Berdasarkan hasil penelitian kekambuhan pada penderita Asma dapat diketahui responden dengan kategori tidak mengalami kekambuhan asma sebesar 18 orang $(34,0 \%)$ dan responden dengan kategori mengalami kekambuhan asma sebanyak 35 orang $(66,0 \%)$. Dapat disimpulkan sebagian besar responden banyak yang mengalami kekambuhan asma dengan manifestasi klinis sesak yang dirasakan sering berulang - ulang.

Penyakit asma tidak dapat disembuhkan, namun dalam penggunaan obat-obat yang ada saat ini hanya berfungsi 
untuk menghilangkan gejala saja. Untuk mengontrol gejala asma secara baik, maka penderita harus bisa merawat penyakitnya, dengan cara mengenali lebih jauh tentang penyakit tersebut termasuk faktor pencetus kekambuhan asma. Mengingat hal tersebut pengelolaan asma yang terbaik haruslah dilakukan pada saat dini dengan berbagai tindakan pencegahan agar penderita tidak mengalami serangan ulang atau kekambuhan. $^{9}$

Menurut peneliti tingginya proporsi responden yang mengalami kekambuhan asma di Wilayah Kerja Puskesmas Cempaka disebabkan karena ada kaitan dengan tingginya proporsi rumah sehat yang tidak memenuhi syarat, sirkulasi udara dan pencahayaan dari ventilasi yang tidak baik, kondisi lantai yang tidak bersih dan barangbarang dikamar kotor dan berdebu merupakan faktor risiko yang dapat menjadi pencetus terjadinya asma.

Begitupun sebaliknya responden dengan kategori tidak mengalami kekambuhan asma dapat disebabkan karena memiliki rumah sehat yang tidak memenuhi syarat sehingga terhindar dari faktor pencetus terjadinya asma.

\section{Hubungan rumah sehat dengan}

\section{kekambuhan pada penderita Asma}

Berdasarkan hasil penelitian pada tabel dapat diketahui bahwa hasil uji statistik chi square didapat nilai $\mathrm{p}$ value $<$ dari $\alpha \quad(0,046<0,05)$ yang artinya Ho ditolak, ada hubungan yang bermakna antara rumah sehat dengan kekambuhan pada penderita Asma di Wilayah Kerja Puskesmas Cempaka. OR didapat 3,929 yang berarti responden dengan rumah sehat tidak memenuhi syarat berpeluang mengalami kekambuhan asma sebesar 3,929 dibandingkan responden dengan rumah sehat memenuhi syarat.

Hasil penelitian ini sejalan dengan penelitian $^{10}$ tentang hubungan faktor sanitasi lingkungan dengan kejadiaan demam tifoid menggunakan metode observational dengan pendekatan Case Control Study pada pasien rawat inap Puskesmas Bobotsari Kabupaten Purbalingga didapat hasil analisa uji $X^{2}$ derajat kemaknaan 95\% ada hubungan yang bermakna sanitasi lingkungan dengan kejadiaan demam tifoid $\mathrm{p}$ Value $=0,003$ $(\mathrm{OR}=3,986 ; 95 \%, \mathrm{CI}=1,165$ - 13,642) dapat disimpulkan kejadiaan demam tifoid berhubungan dengan kondisi sanitasi lingkungan yang buruk. ${ }^{10}$

Salah satu faktor yang dapat mempengaruhi terjadinya kekambuhan asma 
adalah kondisi rumah yang tidak sehat. Konsep tatanan rumah tangga sehat adalah pengaturan rumah sehat yaitu keadaan rumah sebaiknya tidak lembab, cukup ventilasi dan cahaya matahari, kebersihan lantai, kamar tidur sebaiknya sesedikit mungkin berisi barang-barang untuk menghindari debu rumah. Rumah sehat yang tidak memenuhi syarat kesehatan dapat menjadi faktor predisposisi kambuhnya suatu penyakit salah satunya asma. ${ }^{9}$

Merujuk pada teori diatas menurut peneliti terdapatnya hubungan yang bermakna antara rumah sehat dengan kekambuhan pada penderita Asma di Wilayah Kerja Puskesmas Cempaka, pertama disebabkan karena responden dengan kategori rumah tidak memenuhi syarat akan terpapar oleh faktor risiko lingkungan yang merupakan faktor pencetus terjadinya asma seperti ventilasi udaara yang tidak baik menyebabkan sirkulasi udara oksigen pun akan terganggu padahal orang yang mengalami asma membutuhkan suplai oksigen yang lebih banyak dari pada orang yang tidak mengalami asma, pencahayaan yang tidak baik menyebabkan suhu ruangan pun lembab dan lebih banyak dipenuhi oleh $\mathrm{H}_{2} \mathrm{O}$ (Uap air) dari pada oksigen, lantai yang berdebu dan barang-barang yang kotor juga merupakan zat polutan yang dapat memicu pencetus terjadinya asma. Begitupun sebaliknya responden dengan kategori rumah sehat yang memenuhi syarat akan terhindar dari pemaparan faktor-faktor yang menyebabkan terjadinya kekambuhan asma.

Berdasarkan tabel diatas didapatkan hasil bahwa $47,6 \%$ atau 10 dari 21 responden dengan kategori rumah sehat memenuhi syarat mengalami kekambuhan asma, Sedangkan 21,9\% atau 7 dari 32 responden dengan kategori rumah sehat tidak memenuhi syarat tidak mengalami kekambuhan asma.

Asma merupakan gangguan inflamasi kronik jalan napas yang melibatkan berbagai sel inflamasi. ${ }^{7}$ Berdasarkan teori diatas dapat dijelaskan menurut peneliti adanya responden dengan kategori rumah sehat memenuhi syarat mengalami kekambuhan asma dan responden dengan kategori rumah sehat tidak memenuhi syarat tidak mengalami kekambuhan asma kemungkinan disebabkan karena rumah sehat yang memenuhi syarat bukanlah faktor utama yang menyebabkan terjadinya kekambuhan asma, artinya meskipun memiliki rumah sehat yang memenuhi syarat akan tetapi jika mengalami inflamasi kronik jalan napas yang cukup parah maka kejadian kekambuhan asma akan lebih sering terjadi, begitupun 
sebaliknya responden yang tidak terlalu hypersensitif terhadap zat alergen pencetus asma maka meskipun rumah tidak memenuhi syarat maka tidak mudah mengalami kekambuhan asma.

Diperlukan peran serta petugas kesehatan untuk trus mensosialisasikan kriteria rumah sehat yang memenuhi syarat dan memodifikasi rumah yang telah ada secara terperinci dan jelas untuk menghindari terjadinya kekambuhan pada penderita asma.

\section{KESIMPULAN}

Berdasarkan hasil dan pembahasan penelitian hubungan rumah sehat dengan kekambuhan pada penderita Asma di Wilayah Kerja Puskesmas Cempaka dapat disimpulkan:

1. Responden dengan kategori rumah sehat tidak memenuhi syarat sebesar 32 orang $(60,4 \%)$.

2. Responden dengan kategori mengalami kekambuhan asma sebanyak 35 orang $(66,0 \%)$.

3. Ada hubungan yang bermakna antara rumah sehat dengan kekambuhan pada penderita Asma ( $\mathrm{p}$ value $<$ dari $\alpha$, 0,046 $<0,05)$

\section{SARAN}

Penelitian ini diharapkan bagi petugas kesehatan di Puskesmas Cempaka untuk trus mensosialisasikan kriteria rumah sehat yang memenuhi syarat dan memodifikasi rumah yang telah ada secara terperinci dan jelas untuk menghindari terjadinya kekambuhan pada penderita asma.

\section{DAFTAR PUSTAKA}

1. Departemen Kesehatan Republik Indonesia. 2008. Rumah Tangga Berperilaku Hidup Bersih dan Sehat Jakarta: Depkes RI;

2. Diana. 2005. Sanitasi Rumah Dengan Terjadinya Diare Di Posyandu Gendingan Kecamatan Ngmpilan. Yogyakarta.

3. Dinkes Lampung Utara. 2011. Profil Kesehatan Lampung Utara. Lampung Utara

4. Dinkes Provinsi Lampung. 2011. Profil Kesehatan Provinsi Lampung. Bandar Lampung

5. Hastono. 2007. Analisa Data Universitas Indonesia. Jakarta : FKM UI

6. Hidayat.A.Aziz. $2007 . \quad$ Riset Keperawatan. Jakarta : Salemba Medika

7. Mansjoer, Arief. 2001. Kapita Selekta Kedokteran. Jakarta : Media Aesculapius 
8. Notoatmodjo, Sukidjo. 2005. Metodologi

Penelitian. Jakarta : Rineka Cipta

9. Sundaru. 2008. Penyebab dan Faktor

Pencetus Serangan Asma. (online)

(http://medicastore.com/asma/penyebab

dan_faktor_pencetus_asma.php, diakses

pada 14 Februari 2012).

10. Suyono. 2006. Hubungan Sanitasi

Lingkungan Dengan Kejadian Demam

Tifoid Di Puskesmas Bobot Sari

Kabupaten Pubalingga Tahun 2006. 